\title{
Overfishing Drivers and Opportunities for Recovery in Small-Scale Fisheries of the Midriff Islands Region, Gulf of California, Mexico: the Roles of Land and Sea Institutions in Fisheries Sustainability
}

\author{
$\underline{\text { Ana Cinti }}^{1,2}$, Jennifer N. Duberstein $^{1}$, Esteban Torreblanca $^{3}$ and Marcia Moreno-Báez $^{1}$
}

\begin{abstract}
Institutions play an important role in shaping individual incentives in complex social-ecological systems, by encouraging or discouraging resource overuse. In the Gulf of California, Mexico, there is widespread evidence of declines in small-scale fishery stocks, largely attributed to policy failures. We investigated formal and informal rules-in-use regulating access and resource use by small-scale fishers in the two most important fishing communities of the Midriff Islands region in the Gulf of California, which share several target species and fishing grounds. The Midriff Islands region is a highly productive area where sustainable use of fisheries resources has been elusive. Our study aimed to inform policy by providing information on how management and conservation policies perform in this unique environment. In addition, we contrast attributes of the enabling conditions for sustainability on the commons in an effort to better understand why these communities, albeit showing several contrasting attributes of the above conditions, have not developed sustainable fishing practices. We take a novel, comprehensive institutional approach that includes formal and informal institutions, incorporating links between land (i.e., communal land rights) and sea institutions (i.e., fisheries and conservation policies) and their effects on stewardship of fishery resources, a theme that is practically unaddressed in the literature. Insufficient government support in provision of secure rights, enforcement and sanctioning, and recognition and incorporation of local arrangements and capacities for management arose as important needs to address in both cases. We highlight the critical role of higher levels of governance, that when disconnected from local practices, realities, and needs, can be a major impediment to achieving sustainability in small-scale fisheries, even in cases where several facilitating conditions are met.
\end{abstract}

RESUMEN. Resumen: Las instituciones desempeñan un papel importante en la determinación de los incentivos individuales en sistemas socio-ecológicos complejos, alentando o desalentando la sobreexplotación. En el Golfo de California, México, existe amplia evidencia de una marcada disminución en la abundancia de recursos pesqueros de pequeña escala o artesanales, atribuida a fracasos en las políticas de manejo. Este trabajo investiga las reglas formales e informales en uso para regular acceso y uso de recursos por parte de pescadores artesanales en las dos comunidades pesqueras más importantes de la Región de las Grandes Islas, Golfo de California. A pesar de su elevada productividad biológica, el uso sustentable de los recursos marinos en esta región ha sido difícil de alcanzar. Este trabajo proporcionamo información para optimizar el desempeño de los instrumentos de manejo y conservación de recursos marinos presentes en este ambiente único. Además, contrastamos los atributos de las condiciones que facilitan la sustentabilidad en el uso de recursos de uso común, para comprender mejor por qué estas comunidades no han logrado incorporar de manera duradera prácticas de pesca sustentables, a pesar de presentar, en el caso particular de una de ellas, varias condiciones propicias. Adoptamos un enfoque institucional novedoso e integral que incluye instituciones formales e informales, e incorpora los vínculos entre reglas relativas a la tenencia de la tierra (ej. derechos de uso comunales) y del ámbito marino (de pesca y conservación), y sus efectos sobre el cuidado de los recursos marinos, un tópico prácticamente sin abordar en la literatura. Surgen como limitantes importantes en ambos casos, un apoyo gubernamental insuficiente tanto en la provisión de derechos de pesca seguros como en la fiscalización y la aplicación de sanciones, y la falta de reconocimiento e incorporación de arreglos institucionales y capacidades de manejo locales en instancias formales de decisión. Resaltamos el papel fundamental que cumplen los niveles de gobernanza más elevados, los que al estar desvinculados de las prácticas, realidades y necesidades locales, pueden obstaculizar de manera significativa el alcance de la sustentabilidad en pesquerías artesanales, incluso cuando varias condiciones favorables están presentes.

Key Words: communal land tenure; ejido; formal and informal rules-in-use; Gulf of California, Mexico; resource stewardship; small-scale fisheries; social-ecological systems; sustainability

tenencia comunal de la tierra; ejido; reglas formales e informales en uso; Golfo de California; México; sentido de responsabilidad sobre los recursos; pesquerías artesanales; sistemas socio-ecológicos; sustentabilidad

\section{INTRODUCTION}

Current common pool resource ${ }^{[1]}$ theory suggests that given a set of ecological, physical, social, and institutional constraints, people consider the costs and benefits of various behaviors and act according to perceived incentives (Ostrom 1990, Ostrom et al. 2002). Institutions are the rules that people develop to specify "dos and don'ts" related to a particular situation, such as who has access to a resource, what can be harvested, and who participates in key decisions (Ostrom et al. 2002). Rules play an important role in shaping individual incentives in complex social-ecological systems, thus encouraging or discouraging resource overuse (Ostrom 2007). They may comprise a combination of formal, written rules, that are often established by governments, and locally crafted rules - usually unwritten - that are developed by

${ }^{1}$ School of Natural Resources and the Environment, College of Agriculture and Life Sciences, The University of Arizona, ${ }^{2}$ Centro Nacional Patagónico (CENPAT-CONICET), ${ }^{3}$ Pronatura Noroeste, A.C. 
Fig. 1. Map of the study area. The MPAs in the area are: Bahía de los Ángeles, Canales de Ballenas y de Salsipuedes Biosphere Reserve; Archipiélago de San Lorenzo National Park; and Isla San Pedro Mártir Biosphere Reserve.

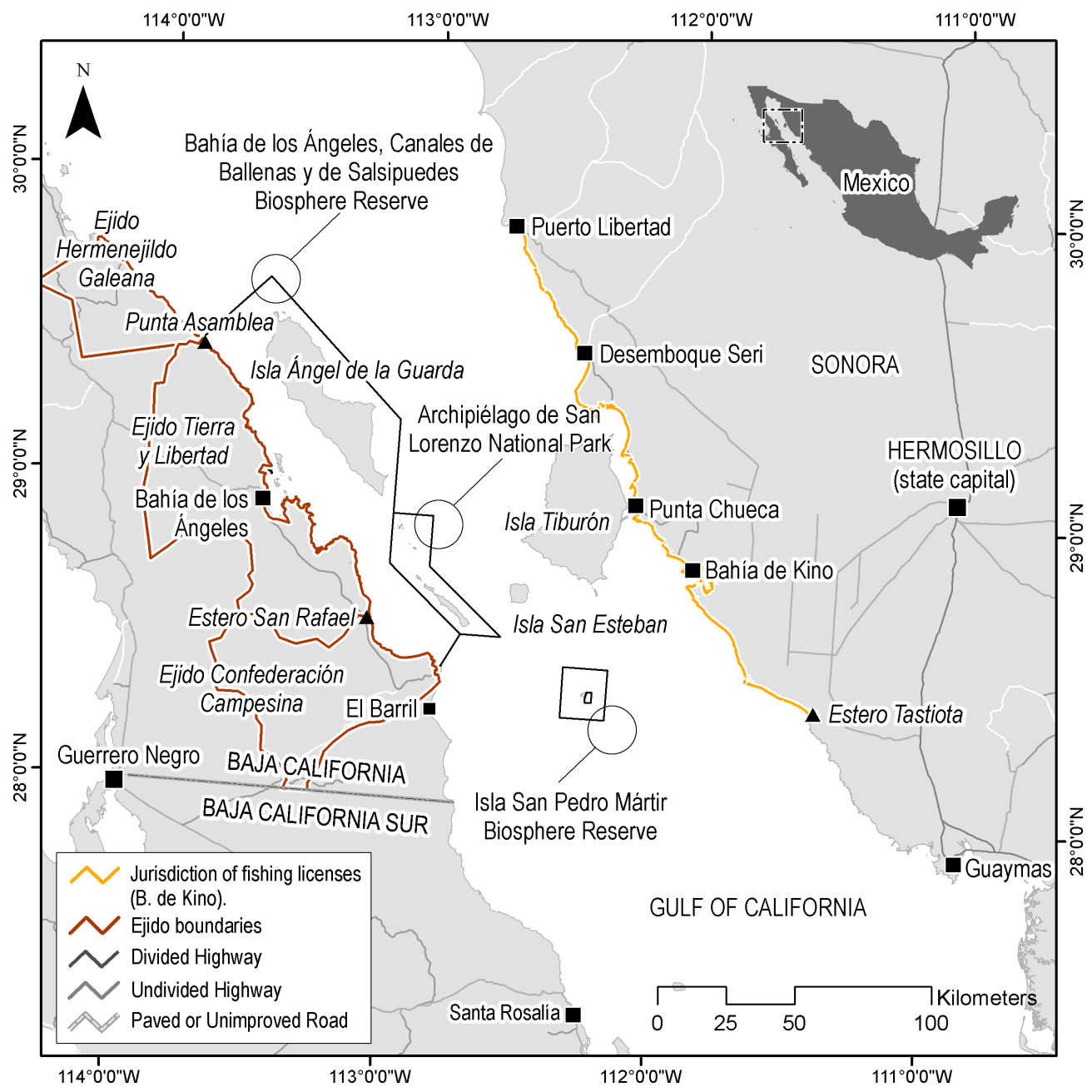

resource users. Rules that are actually used in field settings are called rules-in-use; they may differ substantially from formal laws and are not easily observable. This can lead to erroneous assumptions if managers believe that rules-in-use and formal rules are the same, or that formal rules are the only institutions in place (Ostrom 1992, Ensminger 1996). Studying how rules-in-use, especially those related to access and resource use, affect harvesting behavior is critical for the sustainability of fisheries and other common pool resources.

The Gulf of California, Mexico (Fig. 1) is characterized by exceptionally high levels of primary productivity and biodiversity and outstanding economic and social significance (Carvajal et al. 2004). Fishing, both large scale and small scale, is a predominant economic activity throughout the region. It generates over 50,000 jobs involving approximately 26,000 vessels, of which approximately 25,000 are small-scale boats (Cisneros-Mata 2010). Widespread evidence of declining marine resources in the Gulf of California is largely attributed to policy failures (Alcalá 2003, Greenberg 2006). Recently, however, significant legislative changes, including a new fisheries law, have attempted to address these declines (Diario Oficial de la Federación 2007a).

The goal of our study was to investigate formal and informal rules-in-use that regulate access and resource use by small-scale fishers, and the effects of the rules on fisheries sustainability. The study occurred in Bahía de Los Ángeles on the Baja California peninsula, State of Baja California, and in Bahía de Kino in 
continental Mexico, State of Sonora, both located in the Midriff Islands region (Fig. 1). The Midriff Islands region is an archipelago of 45 islands and islets with a high degree of biological diversity and endemism; it is a highly productive region where sustainable use of fisheries resources has been elusive. Our study aimed to inform policy by providing information on how management and conservation policies perform in this unique environment, in the two most important fishing communities of the area, which share several target species and fishing grounds. In addition, we contrasted attributes of the enabling conditions for sustainability on the commons (Agrawal 2001) in an effort to better understand why these communities, albeit showing several contrasting attributes of the above conditions, have not developed sustainable fishing practices.

Our study took a novel, comprehensive approach that includes formal and informal institutions, incorporating links between land (i.e., communal land rights) and sea institutions (i.e., fisheries and conservation policies) and their effects on stewardship of fishery resources, a theme that is practically unaddressed in the literature. Addressing this link is important because land and sea institutions may interact to create unanticipated rules-in-use, which may either help or hinder sustainable use of fishery resources.

Studies on the commons need to deal with multiple levels of governance and external drivers of change (e.g., impact of government policies and markets) (Agrawal 2001, Berkes 2006). This research is an effort to address this demand by focusing on multiple levels of governance (e.g., land vs. sea institutions; external vs. local governance) and local effects of government policies as external drivers of change.

\section{METHODS}

We used the Institutional Analysis and Development Framework (IAD) (Ostrom 1990) together with Ostrom's classification of rules (Ostrom 1999) to identify potentially relevant variables to explore (institutional, biophysical, and social) and to design datacollection instruments.

We obtained information on formal and informal arrangements that regulate access and resource use by examining legal documents, using semistructured and structured interviews, and by participant observation (Hay 2005, Bernard 2006). Legal documents included fisheries and environmental legislation, documents of formalized groups of fishers (e.g., cooperatives), and official information (e.g., fishing permits issued, statistics). We conducted semistructured interviews with key informants of formalized groups of fishers (typically fishing cooperatives in Bahía de Kino, and Sociedades de Producción Rural ${ }^{[2]}$ in Bahía de Los Ángeles) in order to gather information about internal organization and past and present occurrence of informal fishery arrangements. We also conducted semistructured interviews with key informants from federal agencies about local implementation of management/conservation tools and regulations, enforcement, and access issues. Finally, we conducted structured interviews with captains of small-scale boats. Captains are generally the most experienced and knowledgeable fishers on the boat and tend to make the decisions about fishing (Moreno et al. 2005a).

Structured interviews included: demographic information about respondents (age, sex, place of birth); employment (history of fishing, method of fishing, species targeted, sources of income); organization (membership in formal groups, reasons for joining the group); access to fishing and commercialization of resources (ownership of fishing permits and equipment, autonomy to finance fishing trips, buyers of catch); and perceptions of performance of existing policy tools and regulations. We assessed perceptions through open-ended questions and a set of statements with a five-point Likert scale (strongly agree, agree, neutral, disagree, strongly disagree). Due to the high number of fishing groups in Bahía de Kino, we added a section to the structured interview for gathering additional information about fisheryrelated informal arrangements. For Bahía de Los Ángeles, due to the community's communal land tenure history, we conducted additional semistructured interviews with key informants to explore perceptions of the link between the presence of communal land tenure and the sense of use-rights over fishing grounds.

We conducted research in Bahía de Kino from April to August 2007, focusing on the small-scale fisheries sector of commercial divers (Table 1). In Bahía de Los Ángeles, field work took place from mid November to mid December 2008 (Table 1). The small size of Bahía de Los Ángeles allowed us to extend the study to include gillnets and trap fishing, as well as diving.

We collected information about fishing zones through a rapid appraisal (Beebe 1995) conducted in 2005-2006 in 17 fishing communities of the Gulf of California (see Moreno-Báez et al. 2010 for methodology details). We obtained additional social and biophysical information through literature review.

\section{SOCIO-BIOPHYSICAL ATTRIBUTES OF FISHERIES IN BAHÍA DE LOS ÁNGELES AND BAHÍA DE KINO}

\section{Small and isolated vs. big and connected}

Bahía de Los Ángeles and Bahía de Kino are both rural fishing coastal communities in the Gulf of California (Fig. 1). Bahía de Los Ángeles is a small, isolated community of approximately 500 inhabitants, located over $500 \mathrm{~km}$ from any major cities. In contrast, Bahía de Kino is a much larger community of approximately 5000 inhabitants, situated only $100 \mathrm{~km}$ from the state capital (Hermosillo). In both cases, the closest major cities are primary destinations of local marine resources prior to redistribution to other regional, national, and international markets (primarily the US and Asia).

Bahía de Los Ángeles is a remote location with low influxes of new settlers, where most of the population comprises relatives of the families that were first permanently established in the area (Danemann and Ezcurra 2007). In contrast, Bahía de Kino has received several immigration pulses of people displaced from other coastal communities or from different parts of Mexico, resulting in a more dynamic and heterogeneous population (Doode 2001; Moreno et al. 2005a).

Historically (1930s-present) both communities have been highly dependent on marine resources for their livelihoods (Moreno et al. 2005a, Danemann and Ezcurra 2007). In Bahía de Kino, fishing represented approximately $46 \%$ of the local GDP in 2000 (Moreno et al. 2005a) (data not available for Bahía de Los Ángeles). Our structured interviews indicate that $71 \%$ of respondents relied solely on fishing for their income, compared to $60 \%$ in Bahía de Los Ángeles. 
Table 1. Type and number of interviews conducted in each community.

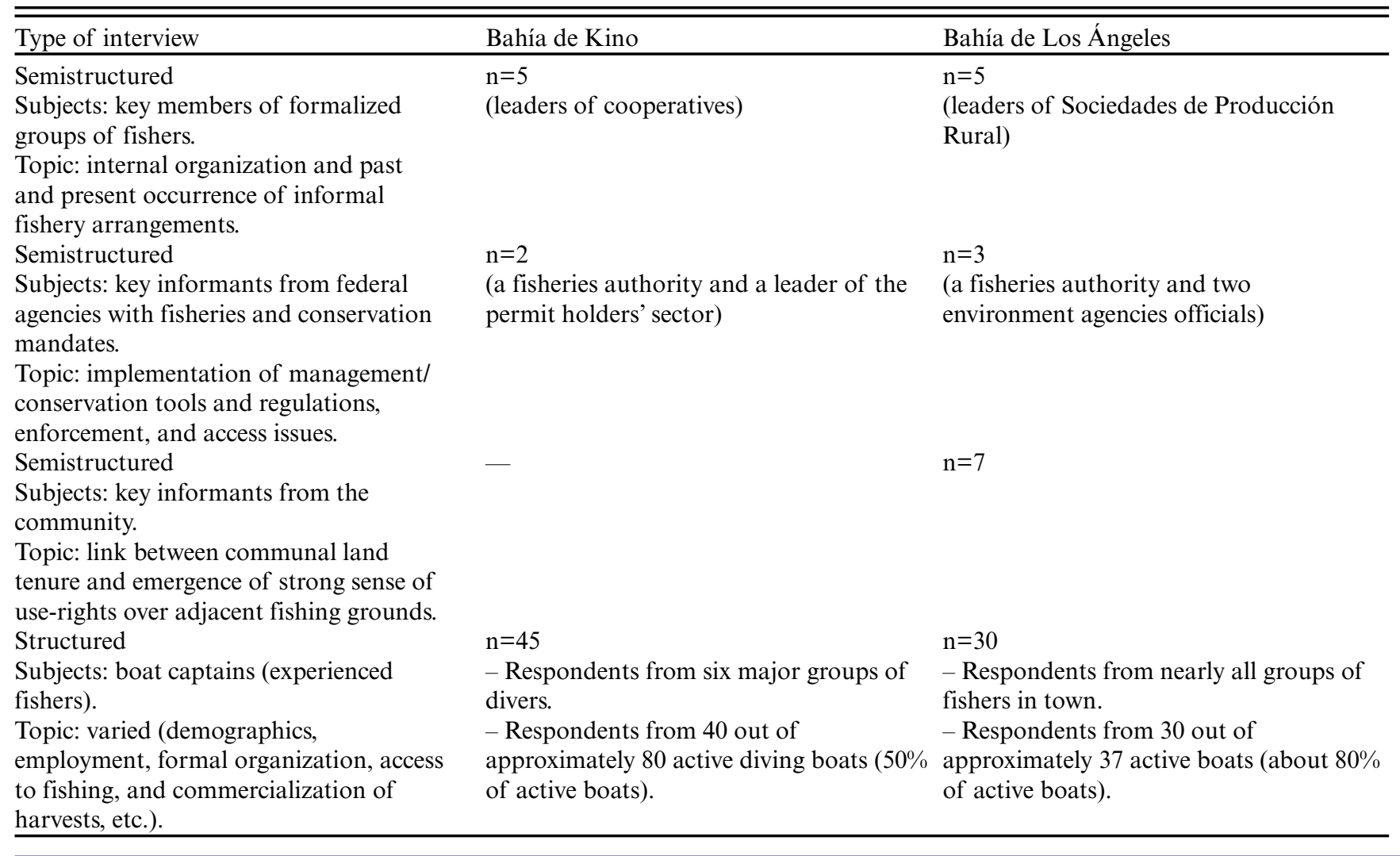

In Bahía de Los Ángeles small-scale fisheries are substantially smaller than in Bahía de Kino, with approximately 70 fishers and 37 boats (Avendaño-Ceceña et al. 2009), and three main fishing methods (main target species in parentheses): gillnets (flounder, Paralichthys californicus; sharks Mustelus spp., Galeorhinus spp.); traps (octopus, Octopus spp; reef fishes, mainly Paralabrax spp.); and hookah diving (octopus; sea cucumber, Istiotichopus fuscus; clams, several species) (Valdez and Torreblanca 2008). Bahía de Kino, in contrast, has approximately 800 fishers and 200 boats actively involved in small-scale fisheries (Comunidad $\mathrm{y}$ Biodiversidad, unpublished data). Approximately 80 boats were active in commercial diving in 2007, targeting primarily pen shells (mainly Atrina spp.), octopus, and reef fishes (groupers and snappers) (see Cinti et al. 2010 $a$ for more detail). Sea cucumber is an important and highly priced fishery for Bahía de Kino divers, though clandestine; the agency governing permits has granted no authorizations for the species in Bahía de Kino. In Bahía de Los Ángeles, in contrast, some users have been granted authorizations for sea cucumber since 2005 .

\section{Overfished resources despite high productivity}

In spite of the outstanding biological productivity of the Midriff Islands region (Álvarez-Borrego 2007), many Bahía de Los Ángeles and Bahía de Kino target species have experienced similar boom and bust cycles, starting with totoaba (Totoaba macdonaldi) in the 1910s and 1920s; shark species in the 1930s; and sea turtles in the 1950s (e.g., Chelonia spp.). Researchers recently detected declines in target species production in both communities.
In Bahía de Los Ángeles, Valdez and Torreblanca (2008) suggested a deterioration of local fisheries, with alarming declines (e.g., sea cucumber, sharks, sand bass). Assessments of sea cucumber stocks in Baja California State in 2010 indicate that the fishery is near collapse (Calderón-Aguilera and Herrero-Perezrul 2011). In spite of this, Bahía de Los Ángeles fishers have a fairly small range (Danemann and Ezcurra 2007), suggesting that they still find it profitable to operate nearby the community (Fig. 2). Interestingly, although it is difficult to access Bahía de Los Ángeles by land, Bahía de Los Ángeles fishing grounds are relatively easy to get to by sea (the minimum linear distance between the Sonoran coast and Bahía de Los Ángeles is $87 \mathrm{~km}$ ) (Valdez and Torreblanca 2008). Bahía de Los Ángeles fishing grounds are frequently visited by small-scale fishers from Sonora (Bahía de Kino, Guaymas, Puerto Libertad) and the Pacific side of the peninsula (e.g., Guerrero Negro) (Fig. 1) (Danemann and Ezcurra 2007), placing even more pressure on the region's resources.

In Bahía de Kino, most target species are overfished (Moreno et al. 2005a, Cinti et al. 2010a). Three decades ago local fishers worked primarily in the waters surrounding Bahía de Kino (Fernández 2003). High immigration and increasing demand for marine resources have resulted in decreasing resource abundance (Moreno et al. 2005b). Currently, local fishers, particularly divers, are regionally known for being highly migratory, using areas as far away as Puerto Peñasco to the north (Cudney-Bueno and Basurto 2009), states south of Sonora (Cinti et al. 2010a), and 
Fig. 2. Fishing zones by community and gear. Source: rapid appraisal conducted in 2005-2006, Proiect PANGAS (Moreno-Báez 2010).
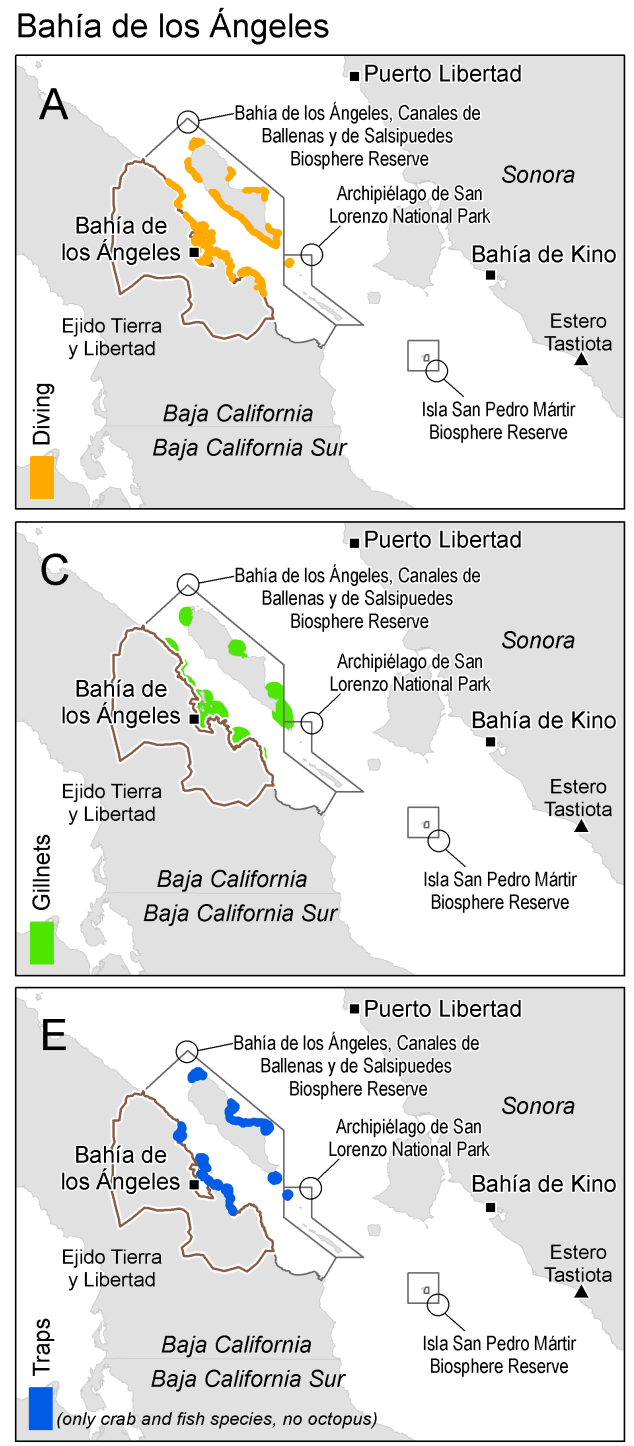

Bahía de Kino
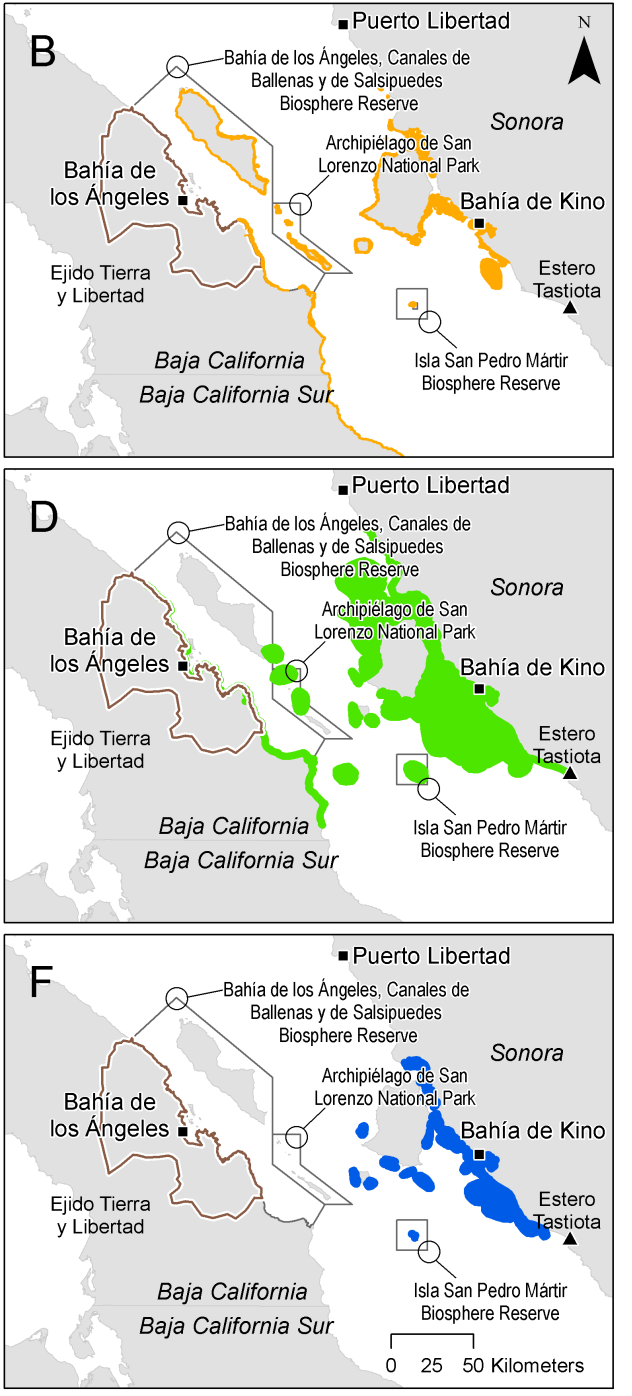

Ángel de la Guarda Island and the gulf coast of the Baja California Peninsula to the west (Fig. 2) (Moreno et al. 2005b). Bahía de Los Ángeles and Bahía de Kino thus have overlapping fishing zones, particularly among divers and gillnet fishers (Fig. 2), who encroach Bahía de Los Ángeles' locally perceived "territory" but not vice versa.

\section{INSTITUTIONAL ATTRIBUTES OF FISHERIES IN BAHÍA DE LOS ÁNGELES AND BAHÍA DE KINO}

Government agencies and tools for fisheries management

Regulation of commercial uses of marine species in Mexico is shared between a set of federal agencies within the fisheries side of government and another set of agencies under the environmental side (Fig. 3). The main tools to regulate access and resource use of marine species include: (a) fishing licenses and concessions; (b) single or multispecies management plans and fishery ordinance plans (programas de ordenamiento pesquero); (c) predios ("Predios Federales Sujetos a Manejo para la Conservación y Aprovechamiento Sustentable de Vida Silvestre", Federal Polygons for the Conservation and Sustainable Use of Wildlife), which are granted for species listed under special protection (listed in the NOM 059-SEMARNAT (Secretaría de Medio Ambiente y Recursos Naturales) (Diario Oficial de la Federación 1994)); and (d) marine protected areas (MPAs) (Fig. 3). Herein we describe fishing licenses, predios, and MPAs because they are the most commonly found management tools in the study area. 
Fig. 3. Federal agencies involved in fisheries regulation in Mexico.

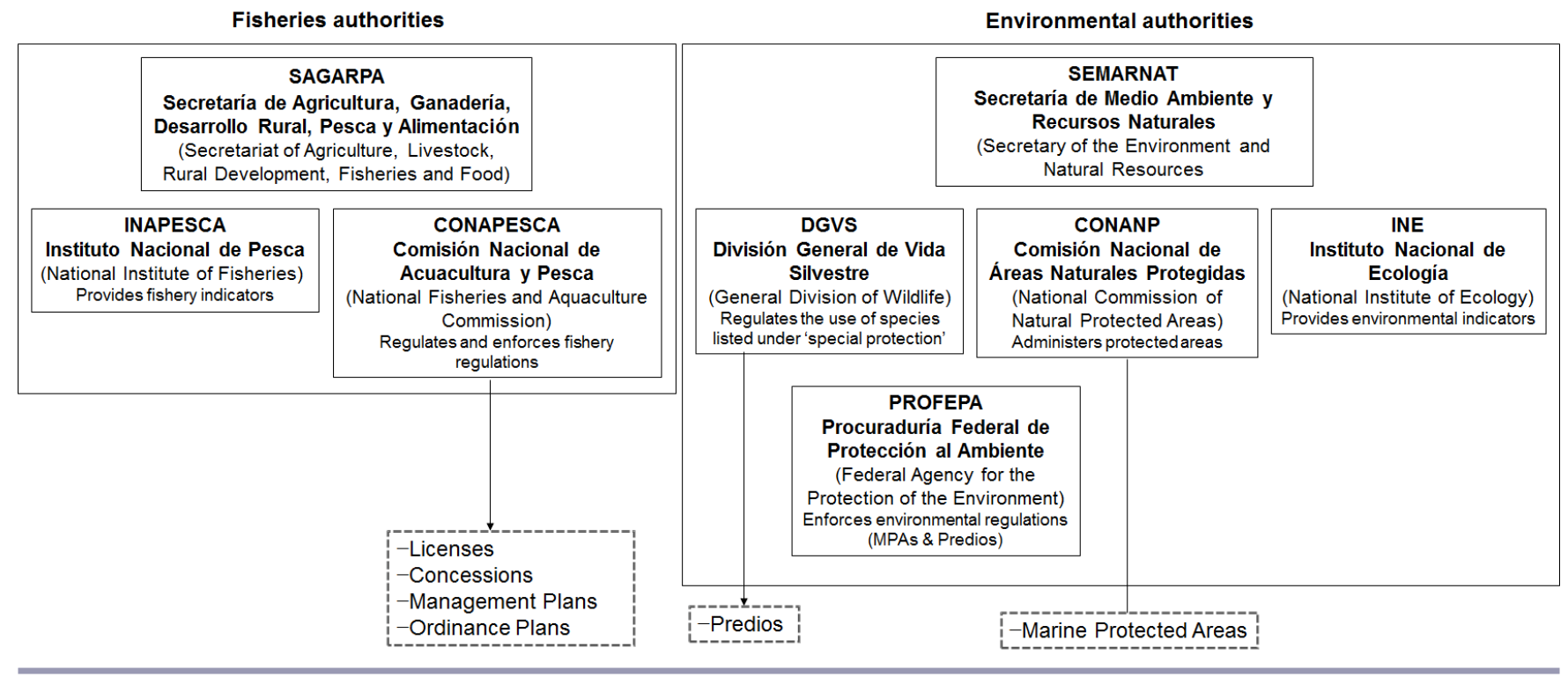

Fishing licenses may be granted to juridical persons (e.g., fishing co-ops, companies) or individuals for a period of 2 to 5 years and are renewable and nontransferable. In order to become a license holder, proof of ownership of fishing equipment (boat and gear) is required; active participation as crew member is not a requisite. The license specifies the species or group of species to be harvested within a broadly specified region. Access to the species and region is generally not exclusive (several license holders may have access to the same species and region), but there are exceptions. In the state of Baja California, for example, licenses for benthic organisms are issued without spatial overlap to avoid conflict (SAGARPA, personal communication). A license holder is allowed to hold several licenses and several boats per license. A boat that belongs to a license holder can be registered on more than one license (i.e., the same boat may fish several species). Each license specifies the number of boats and technical specifications of the fishing equipment (boat, motor, gear) authorized to harvest the species. Only license holders can legally land and declare the catch at regional fisheries offices and provide legal invoices (facturas) for the product. Facturas certify legal ownership of the harvest and are necessary to sell and transport the catch to regional or international markets.

Predios may be granted to juridical persons or individuals for a period of one year. They are renewable upon compliance with regulations and are transferable (Diario Oficial de la Federación 2000). Exclusivity over the permitted species and area does not extend to other species, which can be harvested by others. Grantees must comply with a regional management plan that includes a harvest season and a quota. The latter is based on annual assessments conducted by a research institute, university, NGO, or private consultant, which may or may not involve participation of fishers. Results are reported to a Technical Committee, which advises SEMARNAT (Fig. 3) on quotas and license renewals. A committee is created for each authorized resource or group of resources and for a state or a region within a state. Committees may comprise government agencies (federal, state, or municipal), academic institutions, NGOs, fishers' organizations, industry, and/or other private stakeholders.

The most common type of MPA in the study area is the Biosphere Reserve. It is a multiple-use MPA for which zones with different degrees of protection are delimited; typically there are one or more core zones with higher levels of protection where conservation, education, and research activities are often permitted, and a buffer zone where extractive activities may be allowed. In Mexico, protected area legislation allows for community participation and grants preferential access to community members who live adjacent to the Biosphere Reserve. For example, commercial activities within the buffer zone of Biosphere Reserves can be performed only by the communities who inhabited the area when the MPA is decreed or with their participation (Art. 48, Ley General del Equilibrio Ecológico y la Protección al Ambiente (LGEEPA)). In addition, once an approved management plan is in place, administration of a protected area can be delegated by SEMARNAT to state, municipal, or federal governments; ejidos ${ }^{[3]}$; agrarian communities $^{[3]}$; indigenous communities ${ }^{[3]}$; social groups; and organizations, companies, and other interested juridical and natural persons through formal agreements, provided that they abide by the current laws and management plan (Art. 67, LGEEPA).

In addition to the above, other regulatory instruments for resource use exist in the study area (norms by species, the National Fisheries Chart [see Cinti et al 2010a]); they are not described here because they minimally affect the main target species of Bahía de Los Ángeles and Bahía de Kino. 


\section{Formal rules and rules-in-use in Bahía de Los Ángeles and Bahía de Kino}

In Bahía de Los Ángeles a number of tools coexist. Fishing licenses, the most widespread, are issued for fish and invertebrate species (under Comisión Nacional de Acuacultura y Pesca (CONAPESCA), Fig. 3). Predios exist for sea cucumber (under DGVS). Finally, the Bahía de los Ángeles, Canales de Ballenas y de Salsipuedes Biosphere Reserve extends over the full range of local fishers' fishing grounds (under Comision Nacional de Áreas Naturales Protegidas (CONANP)). In Bahía de Kino, licenses are almost the only tool granted to access marine resources. In addition, the Isla San Pedro Mártir Biosphere Reserve covers only a small portion of local fishers' fishing grounds. Our work in Bahía de Kino did not focus on this MPA.

\section{Authorities' presence and enforcement ability}

The presence of fisheries and environmental authorities differs between the two communities, but the enforcement outcomes are similar-virtually none. In Bahía de Los Ángeles the presence of authorities in charge of regulation and enforcement is not permanent, except for CONANP, which is in charge of MPA administration. This absence makes it difficult for local fishers to submit applications to request or renew licenses and predios or to submit catch declarations. It also hinders agencies' ability to provide support to fishers. Interview results suggest that environmental inspectors visited the community only once or twice in 2008. Information about the arrival of fisheries or environmental inspectors often filters into the community in advance of the visit, giving fishers time to adjust activities and make enforcement ineffective. CONANP can inform enforcement agencies when fishery-related infractions are detected but it has no actual enforcement authority. Although Bahía de Kino has a regional fisheries office with at least one environmental inspector, one or two fisheries inspectors as permanent staff, and permanent CONANP staff in the community, their enforcement capability is limited given the large size of the area and the broad range of activities to oversee (Cinti et al. 2010b).

"Increased support from fisheries authorities" (especially for local presence and enforcement) was among the top four answers of respondents in both communities when members were asked what changes were needed to improve the condition of local fishery resources (Table 2). More than half of respondents in both communities disagreed with the idea that fisheries authorities have had an important role in preventing the depletion of fishery resources. In addition, more than $80 \%$ of respondents in both communities agreed that implementation and enforcement of regulations by local authorities were needed to improve fisheries.

\section{Tools for fisheries management}

Fishing licenses

Table 3 shows the licenses granted in 2008-2009 for all fishing sectors in Bahía de Los Ángeles, and in 2007-2008 for four primary target species of commercial diving in Bahía de Kino (the only available in official statistics). In Bahía de Los Ángeles, octopus and bony and cartilaginous fishes had the highest number of authorized boats, coincident with the salience of these resources for local fishers, while in Bahía de Kino octopus and pen shells were the target species for the bulk of authorized boats.

Access to fishery resources in both communities was concentrated in a few license holders (Table 3) (mostly nonfishers). Of these, only some actively used their permits (in bold in Table 3). In Bahía de Los Ángeles, the majority of license holders resided in major cities (e.g., Ensenada, Tijuana) and did not fish locally. They are generally perceived as illegitimate "outsiders". They use their licenses to shelter catch bought and/or extracted in other regions and declare it as if caught in Bahía de Los Ángeles, or sell invoices to legitimize the commercialization of products caught without a license (Danemann and Ezcurra 2007). Of the 20 Bahía de Los Ángeles license holders in 2008-2009, only six (four individuals and two Sociedades de Producción Rural, in bold in Table 3) live in Bahía de Los Ángeles and actively received and commercialized nearly the entire harvest of local fishers. They are generally seen as legitimate members of the community by local fishers.

In Bahía de Kino, most license holders operated and resided in the community, but in addition to harvesting local resources, they often commercialized products harvested in other communities' jurisdictions, such as Bahía de Los Ángeles. This was due to the high mobility of local divers, who travel long distances to find profitable harvests, as well as the high mobility of local license holders, who buy products from fishers from other communities. Most Bahía de Kino license holders were absentee operators and were generally perceived as a separate, powerful group that often acts against fishers' interests.

Compared to Bahía de Kino, Bahía de Los Ángeles had a higher percentage of fishers who sell their catch using their own licenses: $37 \%$ of Bahía de Los Ángeles respondents compared to none in Bahía de Kino. Bahía de Los Ángeles fishers were also more in control of the capture and commercialization of their harvest than Bahía de Kino fishers: $60 \%$ of Bahía de Los Ángeles respondents owned their fishing equipment compared to $24 \%$ in Bahía de Kino; $20 \%$ of Bahía de Los Ángeles respondents relied on others (license holders or buyers without license) to cover the cost of fishing trips, compared to $91 \%$ in Bahía de Kino (fishers are generally forced to sell the catch to the trip funder).

In both communities, granting fishing permits to local fishers instead of absentee license holders and easing the requirements for locals to access licenses were primary concerns of fishers (Question 1, Table 2).

The number of boats authorized to each license holder in both communities is rarely respected (irrespective of the species in question) and license holders generally launder illegal catches from local, unpermitted fishers. This practice is common throughout the Gulf of California (Bourillón 2002, Moreno et al. 2005a).

Predios

Beginning in 2005, in Baja California, predios were granted for extraction of sea cucumber and almeja pismo (Tivela stultorum) (Avendaño-Ceceña 2007). By 2008-2009, approximately 15 predios had authorized sea cucumber extraction in the state (source: SEMARNAT). Fig. 4 shows the coastal extension of predios (complete polygon coordinates were unavailable) granted inside the Bahía de los Ángeles, Canales de Ballenas y de Salsipuedes Biosphere Reserve and the corresponding quotas per predio holder $(\mathrm{PH})$, totaling 600 tonnes of sea cucumber authorized for extraction inside the Biosphere Reserve during 2008-2009. Only four predio holders actively received sea cucumber from Bahía de Los Ángeles fishers during the study period (indicated in bold in legend of Fig. 4). One corresponded to a Sociedad de Producción Rural of fishers who harvest sea cucumber and are perceived by local fishers as legitimate; the rest 
Table 2. Fishers' perceptions and attitudes about fisheries regulation in Bahía de Los Ángeles' and Bahía de Kino's small-scale fisheries, assessed through structured interviews. ${ }^{\dagger}$

\begin{tabular}{lll}
\hline \hline & Bahía de Los Ángeles & Bahía de Kino \\
\hline $\begin{array}{l}\text { 1. What is missing in terms } \\
\text { of fishery regulation? }\end{array}$ & - Grant fishing licenses to local fishers (57\%). & - Grant fishing licenses to local fishers (22\%). \\
& $\begin{array}{l}\text { - Increase support from authorities (in } \\
\text { enforcement and local presence) }(43 \%) .\end{array}$ & $\begin{array}{l}\text { - Increase support from authorities (in } \\
\text { implementation and enforcement of current } \\
\text { regulations) }(22 \%) .\end{array}$ \\
& - Simplify/expedite paperwork for locals to \\
& access licenses $(20 \%)$. & Control entrance of outsider boats into local \\
&
\end{tabular}

- Regulate resource use (temporal closures, mesh - More respect of regulations (22\%). size, quotas) $(23 \%)$.

2. Fishers' perception of usefulness of fishing licenses to limit access ${ }^{\S}$

3. Fishers' perception of performance of fisheries authorities ${ }^{\S}$
- Fishing licenses were a useful tool to limit access to local fishing grounds: $50 \%$ agreed, $47 \%$ disagreed, $3 \%$ neutral.

- Fisheries authorities have had an important role in preventing the depletion of fishery resources in the community: $23 \%$ agreed, $77 \%$ disagreed.

- In order to improve local fisheries, implementation and enforcement of regulations by local authorities were needed: $87 \%$ agreed, $3 \%$ disagreed, $10 \%$ neutral.

4. Fishers' attitude toward access regulation $^{\S}$

5. Fishers' incentives to join formalized groups $\mid$

6. Usefulness of the biosphere reserve (only assessed in Bahía de Los Ángeles) |
- Only people from the community should be allowed to fish in local fishing grounds: $87 \%$ agreed, 7\% disagreed, $6 \%$ didn't know/did not answer.

- Would prefer working as member of formalized group (47\%). Would prefer working independently $(53 \%)$.

- The reserve has neither benefitted nor been detrimental to them $(71 \%)$.

If given again the choice of establishing a reserve: - Would again decide to have a reserve, mainly to take care of fishing products $(47 \%$ of respondents). Would decide not to have a reserve, mainly because they fear it would bring additional restrictions on fishing (30\% of respondents). Said it does not make any difference to them if there is or there is not a reserve (10\%). Didn't know/had no answer (13\%).
- $40 \%$ agreed with the statement, $56 \%$ disagreed, $4 \%$ neutral.

- $44 \%$ agreed with the statement, $47 \%$ disagreed, $9 \%$ neutral.

$-80 \%$ agreed with the statement, $7 \%$ disagreed, $13 \%$ neutral.

- $64 \%$ agreed with the statement, $31 \%$ disagreed, $4 \%$ neutral.

- Would prefer working as member of formalized group $(40 \%)$. Would prefer working independently (53\%). Didn't know/had no answer $(7 \%)$.

\footnotetext{
${ }^{\dagger}$ Percentages are relative to each sample.

$¥$ Question 1: Open-ended; only top four categories are shown.

${ }^{\S}$ Questions 2 to 4: 5-point Likert scale. Responses "agree" and "strongly agree" are computed together as "\% of agreement".

Responses "disagree" and "strongly disagree" are computed together as "\% of disagreement".

' Questions 5 and 6: Close-ended questions combined with open-ended questions to inquire the reasons behind their answers.
} 
Table 3. License holders with permission to operate in Bahía de Los Ángeles in 2008-2009 (all fishing sectors) and in Bahía de Kino in 2007-2008 (for four main target species of commercial diving). Data source: Comisión Nacional de Acuacultura y Pesca (CONAPESCA).

\begin{tabular}{|c|c|c|c|c|c|c|c|c|c|}
\hline \multirow[b]{2}{*}{ Community } & \multirow[b]{2}{*}{$\begin{array}{l}\text { License } \\
\text { holders }\end{array}$} & \multicolumn{8}{|c|}{ Fishing licenses, by species $^{\dagger}$} \\
\hline & & $\begin{array}{l}\text { Octopus } \\
\text { (no.) }\end{array}$ & $\begin{array}{l}\text { Pen } \\
\text { shell } \\
\text { (no.) }\end{array}$ & $\begin{array}{l}\text { Lobster } \\
\text { (no.) }\end{array}$ & $\begin{array}{l}\text { Geoduck } \\
\text { (no.) }\end{array}$ & $\begin{array}{l}\text { Giant } \\
\text { squid } \\
\text { (no.) }\end{array}$ & $\begin{array}{l}\text { Escama } \\
\text { permit } \S \\
\text { (no.) }\end{array}$ & $\begin{array}{c}\text { Mullet } \\
\text { (no.) }\end{array}$ & $\begin{array}{c}\text { Shark } \\
\text { permit } \\
\text { (no.) }\end{array}$ \\
\hline \multirow{11}{*}{$\begin{array}{l}\text { Bahía de Kino } \\
\text { (diving) }\end{array}$} & JLH 1 & $1(5)$ & & $1(5)$ & & & $1(5)$ & & \\
\hline & JLH 2 & $1(12)$ & $1(12)$ & & & & & & \\
\hline & JLH 3 & $1(8)$ & & & & & $1(8)$ & & \\
\hline & JLH 4 & & $1(4)$ & & & & & & \\
\hline & JLH 5 & & $1(3)$ & & & & & & \\
\hline & ILH 1 & $1(3)$ & $1(7)$ & & & & $1(3)$ & & \\
\hline & ILH 2 & $1(2)$ & & & & & $1(2)$ & & \\
\hline & ILH 3 & $1(2)$ & & $1(2)$ & & & & & \\
\hline & ILH 4 & $1(6)$ & & & & & & & \\
\hline & ILH 5 & & $1(5)$ & & & & & & \\
\hline & ILH 6 & & & $1(3)$ & & & & & \\
\hline $\begin{array}{l}\text { Total (licenses and } \\
\text { boats authorized) }\end{array}$ & & $7(38)$ & $5(31)$ & $3(10)$ & & & $4(18)$ & & \\
\hline \multirow{20}{*}{$\begin{array}{l}\text { Bahía de Los } \\
\text { Ángeles (all } \\
\text { sectors) }\end{array}$} & JLH1 & $1(5)$ & & & & & $1(6)$ & $1(6)$ & $1(3)$ \\
\hline & JLH2 & $1(7)$ & & & & & & & \\
\hline & JLH3 & & & & & $1(2)$ & & & \\
\hline & JLH4 & $1(3)$ & & & & & $1(3)$ & & \\
\hline & JLH5 & $1(3)$ & & & & & $1(3)$ & & \\
\hline & JLH6 & & & & & & & $1(4)$ & \\
\hline & ILH1 & $1(7)$ & & & & & & & \\
\hline & ILH2 & & & & & $1(3)$ & $1(3)$ & & $1(2)$ \\
\hline & ILH3 & & & & & $1(2)$ & $1(2)$ & & $1(2)$ \\
\hline & ILH4 & $1(5)$ & & & & & $1(5)$ & & \\
\hline & ILH5 & $1(4)$ & & & & & & & \\
\hline & ILH6 & & & & $1(3)$ & & & & \\
\hline & ILH7 & & & & & & $1(1)$ & & \\
\hline & ILH8 & & & & & & $1(1)$ & & \\
\hline & ILH9 & $1(2)$ & & & & & $1(6)$ & & $1(2)$ \\
\hline & ILH10 & $1(2)$ & & & & & $1(2)$ & & \\
\hline & ILH11 & & & & & & & $1(2)$ & $1(1)$ \\
\hline & ILH12 & $1(5)$ & & & & & & $1(5)$ & \\
\hline & ILH13 & $\begin{array}{c}1 \\
\text { (unspecified) }\end{array}$ & & & & & & & \\
\hline & ILH14 & $1(1)$ & & & & & & & \\
\hline $\begin{array}{l}\text { Total (licenses and } \\
\text { boats authorized) }\end{array}$ & & $12(44)$ & & & $1(3)$ & $3(7)$ & $10(32)$ & $4(17)$ & $5(10)$ \\
\hline
\end{tabular}

$\dagger$ The number of boats allowed to operate per license and species is indicated between parentheses. Generally, license holders use the same (physical) boats to harvest several species (the same boat is registered in more than one license).

$\ddagger \mathrm{JLH}=$ juridical license holder (typically Sociedades de Producción Rural in Bahía de Los Ángeles and fishing coops in Bahía de Kino). ILH = individual license holder. License holders marked in bold were those that actively received fishing products from local fishers during the study period.

$\S$ The "escama" (fish with scales) license allows fishing 200 bony fish species. In 2007 there were 30 escama licenses total in Bahía de Kino but only four (shown here) were used to report species of fish target of commercial divers (mainly groupers and snappers).

I The shark license allows fishing many elasmobranchs species including rays, sharks, and related species. 
Fig. 4. Coastal extension of predios (complete polygon coordinates were unavailable) granted inside the Bahía de los Ángeles, Canales de Ballenas y de Salsipuedes Biosphere Reserve from late 2007 to late 2008, and the corresponding quotas in tonnes per predio holder.

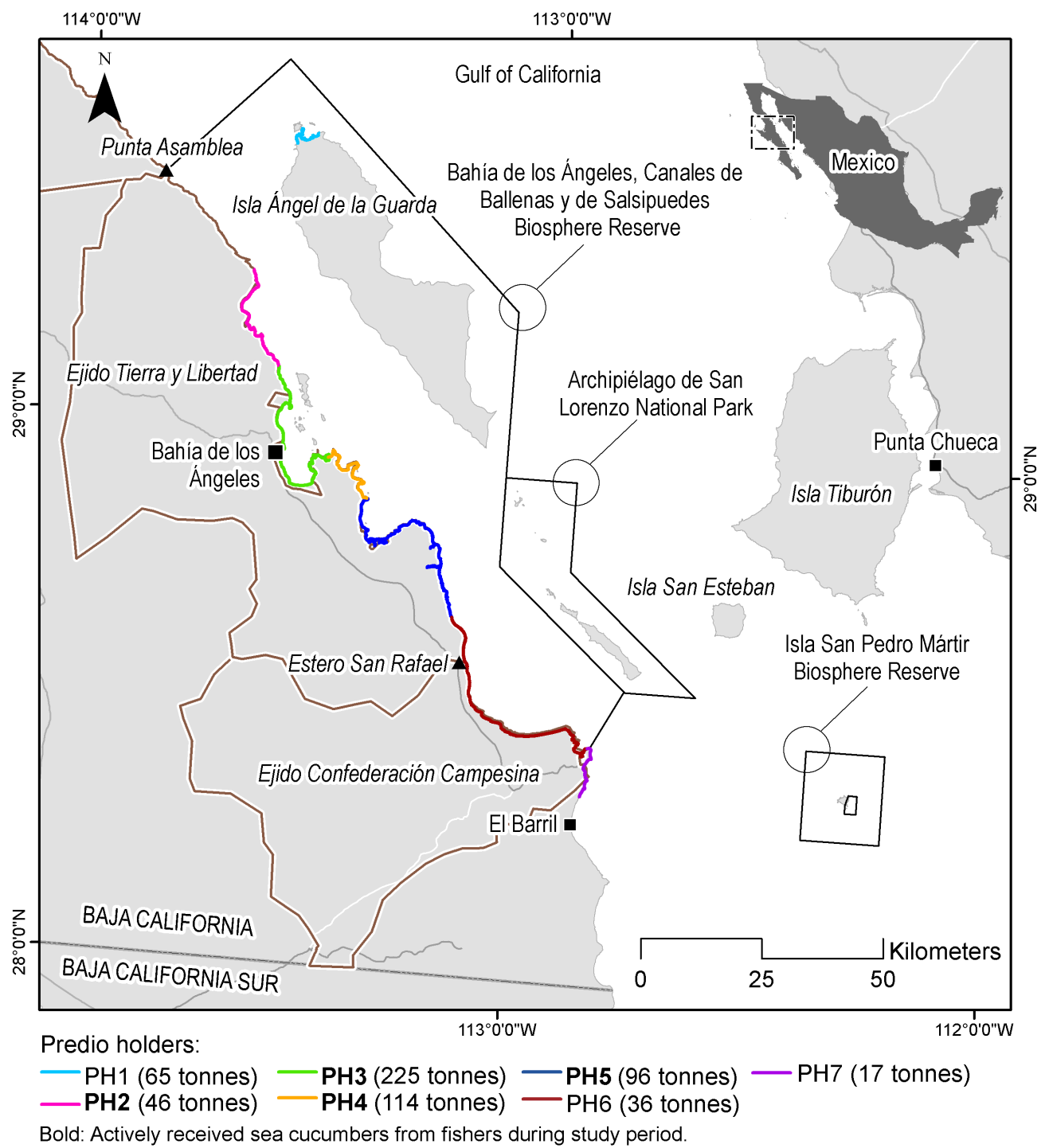

were individual predio holders perceived as illegitimate - an 80year-old mother of local fishers and a married couple (with one predio each) living $500 \mathrm{~km}$ away who bought sea cucumber from local fishers.

There is low compliance with predio boundaries and quotas around Bahía de Los Ángeles, and the resource is severely depleted (Calderón-Aguilera and Herrero-Perezrul 2011). As the only legal way to exploit protected species, predios are used to launder illegal catches, as is often the case for fisheries managed under licenses (Bourillón 2002, Cinti et al. 2010a). The fishing sector does not participate in the state sea cucumber committee (AvendañoCeceña 2007) and although many of the predios are located inside an MPA, resources for enforcement are limited.

\section{MPAs}

The Bahía de los Ángeles, Canales de Ballenas y de Salsipuedes Biosphere Reserve was formally established in June 2007 (Diario Oficial de la Federación 2007b), comprising approximately 385,000 ha. It has the dual purpose of preserving ecological values and enhancing fishery productivity and extends over the full range of local fishers' fishing grounds (Fig. 2). Preferred access to commercial activities (fishing, recreation) inside the buffer zone of the reserve must be granted to the members of the community or communities adjacent to the reserve (Art. 10, Diario Oficial de la Federación 2007b).

At the time of our study, the development of the management plan had not begun (it started in early 2009) and there were no fishery restrictions in place except for six small core-zones, which did not include important fishing areas and forbade extractive uses. Results from interviews suggest that fishing activities 
continued as if no reserve had been established. We asked fishers from Bahía de Los Ángeles whether the reserve had benefitted them and in what ways; if the reserve was detrimental to them and in what ways; and what their decision would be if they were to be given the choice to create a reserve again (see Table 2). Most respondents stated that the reserve has been neither beneficial nor detrimental. Forty-seven percent would still support the creation of a reserve; safeguarding local resources was the most frequent reason expressed, but many also commented that enforcement was necessary. Thirty percent stated that if given the choice again, they would decide against a reserve due to concerns about unwanted restrictions. Ten percent said it would not make any difference to them whether or not there was a reserve.

At the time of our study, lack of enforcement and lack of definition of access rights were critical weaknesses of this MPA. To date, preferential access rights for local fishers are still pending and an increased and stable presence of fisheries and environmental inspectors is still lacking (E. Torreblanca, personal observation).

\section{Fishers' formal organization}

In Bahía de Los Ángeles, the three Sociedad de Producción Rural with fishing licenses were constituted almost entirely by fishers. Most had some indication of incipient cooperative behavior, except for one that functioned as an individual license holder, with one or two absentee operator members in control of the group while the rest worked as independent fishers, selling their catch to the Sociedades de Producción Rural without receiving additional benefits.

In contrast, most formal groups holding licenses in Bahía de Kino, typically cooperatives, functioned in practice as individual license holders (Cinti et al. 2010a). The two cooperatives holding licenses for diving products whose members were all fishers at the time of our study had major administrative problems.

When asked about their associative preferences, about $50 \%$ of respondents from both communities preferred working as part of a formal group, mainly because it improved access to licenses and government benefits (Table 2). The challenges of working as part of a group and greater independence for working and selling one's product were the main reasons for preferring to work independently.

\section{Informal fishery arrangements}

Communal sense of use-rights and defense of "own" territory from outsiders

In Bahía de Los Ángeles, the presence of a coastal "ejido" (a system of communal land tenure) generates a strong "sense of use-rights" among community members over the fishing grounds within ejido limits, as if land rights have been informally extended to include the adjacent sea. The sea territory within ejido limits - from Punta La Asamblea to Estero San Rafael (Fig. 1) - is considered part of the community and is where members fish (Fig. 2), disregarding the spatial boundaries of existing formal management tools. For example, fish species' licenses are generally granted for large geographic areas (some are valid for the entire Gulf of California), with the requisite that the catch be landed in Bahía de Los Ángeles, whereas benthic species licenses and predios include relatively small areas located "inside" ejido borders. In Bahía de Los Ángeles it is locally accepted that as long as you belong to the community, you are allowed to fish anywhere within ejidal limits.

Ejido Ganadero, Turístico y Pétreo Tierra y Libertad (or Ejido Tierra y Libertad) (Fig. 1) was founded in Bahía de Los Ángeles in 1970; it consisted of 62 members (Vargas et al. 2007), most of whom were dedicated to fishing. Today, it consists of about 90 members, with approximately $90 \%$ dedicated to fishery-related activities and/or tourism and 10\% to cattle ranching (F. Smith and A. Reséndiz, personal communication).

Interviews suggest that this communal, informal sense of userights among Bahía de Los Ángeles residents (not just ejido members) over the adjacent sea started to emerge when the ejido and the Sociedad Cooperativa de Producción Pesquera Ejidal Canal de Ballenas, or SCPPECB, were formed. The SCPPECB was the first fishing cooperative in Bahía de Los Ángeles and was founded in 1970, following the foundation of the ejido. The SCPPECB facilitated access to fishing licenses for legal harvesting of sea turtle, which were available only to formal groups (I. Verdugo, personal communication). When ejidos were established in the area, adjacent ejidos started to claim the fishing grounds within their own ejidal limits; each ejido's boundaries were generally respected without the need for external intervention $(\mathrm{F}$. Smith, personal communication). The relationship between neighboring ejidos has been relatively good over time and crossing boundaries was mutually accepted. It was not until the past 10 to 15 years, with the arrival of boats from distant communities on the Sonoran coast and the Pacific side of the Baja California peninsula, that Bahía de Los Ángeles residents started to enforce ejidal limits more vigorously. The influx of boats from distant communities is considered an intrusion by Bahía de Los Ángeles residents, which increased demand for support from fisheries authorities, including formal requests by ejido leaders to expel outsiders. In Bahía de Los Ángeles, the community organizes to discourage outsiders, generally without authorities' intervention. The remoteness of Bahía de Los Ángeles makes it relatively easy for residents to use simple strategies like agreeing not to sell or provide drinking water to outsiders. Local fishers generally reject not only the intrusion of boats but also the arrival of fishers from distant communities looking for an opportunity to work in local boats.

In Bahía de Kino, although there is no ejido, residents also tend to reject the intrusion of boats from other communities. Local fishers consider their territory to generally coincide with the jurisdiction of fishing licenses, approximately from Puerto Libertad to Estero Tastiota (Fig. 1), irrespective of whether fishers hold a license. The exception is the Infiernillo Channel, which is recognized as Seri territory (Basurto 2005). Access to local fishing grounds by outsiders, especially from southern Sonora, Sinaloa, and Nayarit, generates strong conflicts (Cinti et al. 2010a). Local fishers and community members react by organizing protests or blocking the paved road into town. This occurs regardless of the fact that local divers encroach on other communities' territories. Fishers are, however, generally willing to accept fishers from outside the community if they work as crew members on local boats.

Generally, neither Bahía de Los Ángeles nor Bahía de Kino fishers enforce the individual boundaries of the licenses or predios they hold or work under, but they do care about and defend the area 
that they perceive as belonging to their community as a whole. A large percentage of respondents in both communities agreed that only locals should be allowed to fish in local fishing grounds; an appreciably higher percentage felt this way in Bahía de Los Ángeles versus Bahía de Kino (87\% and 64\%, respectively, Table 2).

\section{ENABLING CONDITIONS FOR SUSTAINABILITY AND SELF-ORGANIZATION}

To illustrate similarities and differences between communities, we used the list of critical enabling conditions for sustainability on the commons (Agrawal 2001) and a set of contextual variables that affect the probability of users developing or changing rules (Ostrom 2007) (Table 4). The comparison is descriptive (no ranking system), but is based on an expert knowledge of the area by the research team.

While fishers in neither Bahía de Los Ángeles nor Bahía de Kino have successfully organized to develop institutions for sustainable use of marine resources, Bahía de Los Ángeles shows many of the critical enabling conditions for sustainability on the commons and self-governance (Table 4), most notably: a smaller size of users and resources; more clearly defined group and resource boundaries; greater ease of enforcement of rules due to community isolation, small user group size, and lower cost exclusion technology; higher level of shared norms, homogeneity of identities and interests, and locally devised rules (ejido institutions playing a key role); and lower levels of articulation with external markets. Despite differences in the type of policy tools governing these two fishing communities, both show similar insufficiencies with regards to support received from the government in provision of secure rights, enforcement and sanctioning, and recognition and incorporation of local arrangements and capacities for management. These issues relate to the local effects of higher levels of governance and can be considered, following Agrawal (2001) and Berkes (2006), as factors of the external environment.

In light of the distinctive attributes of the two communities, Bahía de Los Ángeles shows a higher potential for achieving sustainability of resource use and for local users to participate in self-governance in the short- to midterm than Bahía de Kino.

\section{DISCUSSION}

Both communities have unsecure tenure rights, poor or null participation of fishers in decision and rule making, a lack of government recognition of local fishery arrangements, and a lack of government support for enforcement, all of which are critical for fisheries sustainability.

Security of tenure rights is a condition recurrently observed in long-enduring common pool resource institutions, as stated in Ostrom's design principle 7 , minimal recognition of rights to organize (Ostrom 1990): " . . . the rights of users to devise their own institutions are not challenged by external government authorities, and users have long-term tenure rights to the resource" [emphasis added].

Security of tenure rights has gained particular attention in the case of fisheries in recent decades (Christy 2000, Charles 2002, FAO 2002, Hilborn 2005). In small-scale fisheries, the conventional approach to fisheries management (top-down, assessment-dependent systems, reliant on external enforcement) has been generally ineffective (Mahon 1997, Berkes et al. 2001). Management approaches are shifting towards participatory systems reliant on incentives, where the provision of long-term use rights in a variety of forms (see Orensanz et al. 2013 for examples from Latin American benthic small-scale fisheries) is thought to be a necessary step for incentivizing responsible use (Hilborn et al. 2005, Orensanz et al. 2005). In our case studies, neither community (as of 2012) has long-term use rights to the resources, not only because fishing authorizations are not held by fishers in most cases and access rights to MPAs are loosely defined, but also because current policy tools (licenses, in particular) are loose access regimes (Orensanz et al. 2013) which do not provide exclusivity of use in the long term. Institutional mechanisms for strengthening tenure security for fishers should be pursued in both communities and security of tenure should probably receive an explicit mention as a separate enabling condition for sustainability.

Lack of involvement of fishers in management and policy decisions, as well as lack of government recognition of informal fishery arrangements, can be improved with implementation of incentive systems for long-term use rights. This generally implies devolution of management authority and increased autonomy at the local level. "Participation in the creation and modification of rules by those affected by management regimes" (Ostrom's design principle 3 (Ostrom 1990)) and "government recognition of the rights of users to devise their own rules" (Ostrom's design principle 7 (Ostrom 1990) and Agrawal's condition 30 (Agrawal 2001)) are recurrently observed in long-enduring common pool resource institutions. Local participation and autonomy may provide management regimes with the necessary flexibility and adaptability to adjust to local and external conditions (Berkes et al.2003) and increase rule legitimacy for those involved in creating them (likely increasing compliance), as opposed to rules externally imposed. Management regimes should also be flexible enough to consider informal tenure arrangements (Johannes 1978, Berkes 2006, Orensanz et al. 2013). Even though Bahía de Los Ángeles and Bahía de Kino fishers who are members of formalized groups do have some level of autonomy for devising internal rules, participation in management decisions and rule making is practically null. Tenure insecurity from highly informal fishing practices greatly contributes to this issue. In addition, informal fishery arrangements (including those related to ejido land rights) have not been recognized nor incorporated into management and conservation strategies by the government in either community.

The third issue we highlight is the lack (or inefficiency) of supporting external sanctioning institutions (Agrawal's condition 31 (Agrawal 2001)) that results in de facto open access. There is general agreement that rules must be enforced in some manner to achieve robust governance (Ostrom 1990); the presence of local monitoring of harvesting behavior is characteristic of most longsurviving resource regimes (design principle 4). External support for enforcement is also critical to help protect local institutions and incentivize compliance (Christy 2000, Berkes 2006). Although both Bahía de Los Ángeles and Bahía de Kino have some informal sanctioning processes against outsiders, these are not sufficient. Bahía de Kino is generally an open access system. In Bahía de Los Ángeles, although simple strategies have been effective in limiting outsider entry in areas close to town, areas 
Table 4. Critical enabling conditions for sustainability on the commons (after Agrawal 2001) and institutional emergence (marked with asterisks, indicating the corresponding variable of the SES framework) (after Ostrom 2007) applied to Bahía de Los Ángeles' and Bahía de Kino's small-scale fisheries.

\begin{tabular}{|c|c|c|c|}
\hline Category & Attributes & Bahía de Los Ángeles & Bahía de Kino \\
\hline \multirow[t]{6}{*}{$\begin{array}{l}\text { Resource } \\
\text { system }\end{array}$} & $\begin{array}{l}\text { 1. Small size }(* \\
\text { RS3) }\end{array}$ & Yes & No \\
\hline & $\begin{array}{l}\text { 2. Well-defined } \\
\text { boundaries }\end{array}$ & $\begin{array}{l}\text { Yes: fishers work in a clearly defined region } \\
\text { that coincides with the limits of the MPA. }\end{array}$ & $\begin{array}{l}\text { No: Bahía de Kino fishers work over a broad, } \\
\text { continually expanding area. }\end{array}$ \\
\hline & $\begin{array}{l}\text { 3. Low levels of } \\
\text { mobility (*RU1) }\end{array}$ & $\begin{array}{l}\text { Generally yes: several target species can be } \\
\text { considered of low mobility (e.g., diving } \\
\text { resources, trap resources, flounder). }\end{array}$ & Yes, especially in the case of diving resources. \\
\hline & $\begin{array}{l}\text { 4. Possibility of } \\
\text { storage of benefits } \\
\text { from the resources }\end{array}$ & $\begin{array}{l}\text { Yes/Mixed: more respect for territories and } \\
\text { restricting access although there is increasing } \\
\text { pressure from outsider fishers. }\end{array}$ & $\begin{array}{l}\text { No: even for benthic species, there is great } \\
\text { pressure from other fishers/tragedy of the } \\
\text { commons situation. }\end{array}$ \\
\hline & $\begin{array}{l}\text { 5. Predictability }(* \\
\text { RS7) }\end{array}$ & $\begin{array}{l}\text { Moderate: for certain species, such as sea } \\
\text { cucumber, fishers are conducting monitoring } \\
\text { and can anticipate future harvest. }\end{array}$ & $\begin{array}{l}\text { No: even for species where fishers are conducting } \\
\text { monitoring, the lack of access control makes } \\
\text { predictability difficult. }\end{array}$ \\
\hline & $\begin{array}{l}\text { Productivity of the } \\
\text { system (*RS5) } \\
\text { (variable not } \\
\text { included in } \\
\text { Agrawal's list) }\end{array}$ & $\begin{array}{l}\text { Scarce for several species although with } \\
\text { possibilities for recovery due to highly } \\
\text { productive environment. }\end{array}$ & $\begin{array}{l}\text { Scarce for most species, although with } \\
\text { possibilities for recovery due to highly productive } \\
\text { environment. }\end{array}$ \\
\hline \multirow[t]{9}{*}{ Users } & $\begin{array}{l}\text { 6. Small groups }(* \\
\text { U1) }\end{array}$ & Yes & No \\
\hline & $\begin{array}{l}\text { 7. Clearly defined } \\
\text { boundaries }\end{array}$ & $\begin{array}{l}\text { Yes: fishers tend to belong to one group and } \\
\text { only work with that group; community } \\
\text { membership is fairly clear. }\end{array}$ & $\begin{array}{l}\text { No: although fishers may belong to a particular } \\
\text { group, boundaries are fluid and individuals may } \\
\text { work with multiple groups; community } \\
\text { membership is dynamic. }\end{array}$ \\
\hline & $\begin{array}{l}\text { 8. Shared norms }(* \\
\text { U6) }\end{array}$ & Yes: ejido plays key role. & $\begin{array}{l}\text { No/Mixed: although fishers may have shared } \\
\text { norms, there also exist mechanisms for getting } \\
\text { around those norms. }\end{array}$ \\
\hline & $\begin{array}{l}\text { 9. Good leadership } \\
(* \mathrm{U} 5)\end{array}$ & $\begin{array}{l}\text { Yes: } 52 \%(\mathrm{n}=81) \text { thought there was someone } \\
\text { in the community who could serve as a } \\
\text { representative for fishers and one person } \\
\text { received } 27 \% \text { of the vote (Duberstein } 2009) \text {. }\end{array}$ & $\begin{array}{l}\text { No: only } 37 \%(n=81) \text { felt there was someone in } \\
\text { the community who could serve as a } \\
\text { representative for fishers, and one person } \\
\text { received } 13 \% \text { of the vote (Duberstein } 2009) \text {. }\end{array}$ \\
\hline & $\begin{array}{l}\text { 10. Past successful } \\
\text { experience }\end{array}$ & $\begin{array}{l}\text { Yes/Mixed: some challenges in the past, but } \\
\text { recent successful experiences have created a } \\
\text { basis for future successes. }\end{array}$ & $\begin{array}{l}\text { No/Mixed: some success in the past, but in recent } \\
\text { years fishers have mainly faced challenges. }\end{array}$ \\
\hline & & Yes/mixed: in functional Sociedades de & No/Mixed: fishers are largely dependent on \\
\hline & $\begin{array}{l}\text { Interdependence } \\
\text { between group } \\
\text { members }\end{array}$ & $\begin{array}{l}\text { Producción Rural members have different } \\
\text { skills and responsibilities. }\end{array}$ & license holders. \\
\hline & $\begin{array}{l}\text { 12. Similarities in } \\
\text { identities and } \\
\text { interests }\end{array}$ & $\begin{array}{l}\text { Yes: Bahía de Los Ángeles is a small town } \\
\text { where most people have grown up together } \\
\text { and there is a lower amount of outside } \\
\text { influence and therefore more homogeneity in } \\
\text { identities and interests. }\end{array}$ & $\begin{array}{l}\text { No/Mixed: Bahía de Kino, with its close } \\
\text { proximity to the state capital of Hermosillo, as } \\
\text { well as the nearby agricultural town of Miguel } \\
\text { Aleman and a regular influx of tourists from } \\
\text { elsewhere in the country and the U.S., has many } \\
\text { outside influences. Although fishers have a } \\
\text { certain level of similarity in identities and } \\
\text { interests, these outside factors result in more } \\
\text { heterogeneity. }\end{array}$ \\
\hline & $\begin{array}{l}\text { 13. Low levels of } \\
\text { poverty }\end{array}$ & $\begin{array}{l}\text { No/Mixed: similar situation to Bahía de } \\
\text { Kino, although Bahía de Los Ángeles fishers } \\
\text { seem to have made the leap to ecotourism in a } \\
\text { way that Bahía de Kino fishers have not. }\end{array}$ & $\begin{array}{l}\text { No/Mixed: fishers generally do not make much } \\
\text { money, although some live quite well (especially } \\
\text { those who work in black market species); license } \\
\text { holders, in particular, make a good living. }\end{array}$ \\
\hline
\end{tabular}


14. Overlap between user group the community of Bahía de Los Ángeles. residential location and resource location

15. High levels of dependence on the resource system ${ }^{*}$ U8)

16. Fairness in allocation of benefits from common resources

\section{Low levels of user demand in level of demand Knowledge of (*U7) (variable not included in Agrawal's list).} 18. Gradual change No SES/mental models and clearly defined fishing territory.

Institutional 19. Rules are framework simple and easy to understand 20. Locally devised access and management rules (*GS5 \& GS6)

21. Ease in enforcement of rules 22. Graduated sanctions 23. Availability of low-cost adjudication 24. Accountability of monitors and other officials to users

25. Match restrictions on harvests to regeneration of resources

External 26. Low-cost environment exclusion technology
Yes: some fishers are venturing into tourism, although the remote location of the community makes this a limited venture. Because Bahía de Los Ángeles fishers work within a discrete region, they are more dependent on the resource system.

Yes/Mixed: benefits seem to generally be reasonably fairly distributed among crew or SPR members; there also exist situations where the license holder (and not the fisher) receives a large proportion of the benefits.

Moderate

\section{No}

Probably more complete due to the smallness

Yes/Mixed

Yes: Bahía de Los Ángeles fishers have a more organized system of mechanisms for delineating boundaries and restricting access to outside fishers.

Mixed: would be greatly eased with external support.

Mixed: some Sociedades de Producción Rural have some graduated sanctions.

No: conflicts are informally resolved.

No: inspectors and other officials are generally accountable to higher level authorities.

Yes/Mixed: exists for sea cucumber, for which monitoring is carried out, although harvests have exceeded regeneration; not as much for other species for which monitoring programs currently do not exist.

Yes: simple mechanisms like not providing water or not buying the catch of outside fishers create a no-cost means to discourage fishers from outside from working in the region.
No

No/Mixed: Bahía de Kino fishers have a large work area, some of which is close to the community and some is distant. Bahía de Kino stands out among other communities in the Gulf by having fishers that travel long distances to work.

Mixed/Yes: proximity to other population centers, tourism, construction, etc. gives options; due to the large size of the fishing zone, Bahía de Kino fishers are less dependent on a single area or fishery.

No: license holders receive a disproportionate amount of benefits from common resources, as well as fishers from other communities. However, benefits made by the crew seem to generally be reasonably fairly distributed among crew members

No

No

Probably less complete than in Bahía de Los Ángeles due to the diffuseness of their fishing territory.

No/Mixed: although fishers have a sense of home territory and purport to resist efforts of outsiders to fish within this range, the system is largely open access.

No: enforcement of rules is much more difficult in Bahía de Kino due to high accessibility and the size of the territory to oversea.

No: generally no sanctions are applied.

No: conflicts are informally resolved.

No: inspectors and other officials are generally accountable to higher level authorities.

No/Mixed: although some groups have tried to institute monitoring efforts and match harvest to monitoring results, lack of ability to restrict access makes limiting harvest nearly impossible.

No 
27. Time for adaptation of new technologies related to the commons 28. Low levels of articulation with external markets

Yes: at level of fisher. No: at level of buyer/ license holder; shows lower levels overall than Bahía de Kino.

29. Gradual change Moderate: with improved internet and in articulation with communication, these changes are becoming external markets more rapid, although the lack of technology in fisher homes and the community in general, as well as geographic isolation, makes this process slower in Bahía de Los Ángeles.

30. No Moderate: although the same situation exists undermining of in Bahía de Kino, in Bahía de Los Ángeles local authorities by fishers have demonstrated more success in central government local governance and in working with central government (with Comision Nacional de Áreas Naturales Protegidas (CONANP) in particular) to maintain this success; an NGO (PRONATURA) has provided critical support to facilitate access of fishers to fishing licenses and foster participation in management.

31. Supporting No

external sanctioning institutions 32. Appropriate levels of external aid to compensate local users for conservation actions 33. Nested levels of appropriation, provision, enforcement, governance

Moderate/Yes: a small group of fishers receives income for participating in monitoring activities $43 \%$ have received financial support through government programs (Duberstein 2009).
No/Mixed: pressure from other fishers/tragedy of the commons situation limits the amount of time available for adaptation to new technologies.

Mixed/Yes: at level of fisher-proximity to Hermosillo/other population centers makes it easier for fishers to connect with external markets. No: at level of buyer/license holder. Moderate: with improved internet and communication, these changes are becoming more rapid.

No: central government regulations (e.g., for licenses, for reporting catch) make it challenging for many fishers to gain legal access to the resource and make it easy for license holders to retain power. An NGO (Comunidad y Biodiversidad) has provided critical support to facilitate access of fishers to fishing licenses and foster participation in management, but success has been limited due to enormous challenges.

No

No/Moderate: a small group of fishers receives income for participating in monitoring activities; $19 \%$ have received financial support through government programs (Duberstein 2009).

No/Mixed: articulation between higher and local levels of governance has been generally poor. located farther away, like Ángel de la Guarda Island, are difficult to control without external support. Despite recent efforts to improve enforcement through an interinstitutional enforcement committee (with fisheries and environmental authorities) and a community enforcement team, increased and stable presence of inspectors is still lacking.

The set of issues described above is related to the lack or inefficiency of cross-scale governance (Berkes 2006) or nested enterprises (Ostrom's design principle 8 (Ostrom 1990) and Agrawal's condition 33 (Agrawal 2001)), where higher and local levels of governance do not effectively complement each other to prevent overuse.

Results of comparative studies in small-scale fisheries clearly demonstrate that the above factors facilitate sustainability. Orensanz et al. (2005) compared three management regimes of benthic small-scale fisheries in South America and suggested management prescriptions such as the promotion of systems that provide long-term use rights; the promotion of participation of fishers and other stakeholders, managers, and scientists in joint discussions of management issues; and capitalizing on fishers' knowledge. Cinner et al. (2012) studied the occurrence of Ostrom's design principles in 20 long-enduring and dynamic small-scale fisheries systems in Indonesia, Papua New Guinea, and Mexico and highlighted three trends: most cases had clearly defined resource boundaries and membership, all cases had flexibility and autonomy in making and changing rules, and most cases lacked cross-scale linkages with higher levels of governance, suggesting that they may lack the institutional embeddedness required to confront some common pool resource challenges (Cinner et al. 2012). Orensanz et al. (2013) studied the performance of 20 management regimes of benthic small-scale 
fisheries in Latin America and suggested as the most salient lessons "the need to attend to the multiple aspects of sustainability (biological, social, economical, institutional) when a system is implemented, providing for flexibility and adaptiveness, creating ambits for interaction among stakeholders, and counting on transparent and effective support from the state regarding enforcement, legislation and courts."

There are many factors that account for fisheries sustainability, and those we emphasized in this study are not the only important aspects to consider. Nonetheless, the factors we highlighted here arise as important needs to address in order to achieve long-term sustainability.

Studies that address the links between land and sea institutions and their effects on stewardship of fishery resources (freshwater or marine) are practically unaddressed in the literature. To the best of our knowledge, only two published articles have addressed links between land institutions and their effects on some aspect of fishery resource use or management (freshwater or marine). Basurto (2006) documented that the communal ownership of the land by the Seri, an indigenous group by the east Gulf of California coast, gives them more authority to determine with whom they will conduct business, providing more bargaining power at the moment of commercializing their harvests. ArceIbarra and Charles (2008) working in freshwater fisheries inside ejidos of Quintana Roo, Mexico, found that resources within these ejidos can be considered open access. Protection of fishery resources from people wanting to access them is weak; the authors suggest that this might be due to the secondary role of fishing as a source of income for these communities. The present study presents for first time a case where ejidos have a strong effect on how the members of a community perceive and defend their rights to access the marine resources located adjacent to their communal land but formally outside the boundaries. In Bahía de Los Ángeles, land institutions have perhaps stronger impacts on decisions affecting fishery resource use than rules specifically created to manage fisheries, likely due to the salience of fishing for Bahía de Los Ángeles residents. This underscores the importance of fully understanding local rules-in-use when designing management strategies and developing laws and regulations.

\section{CONCLUSIONS}

Our study investigated formal and informal rules-in-use regulating access and resource use by small-scale fishers in the two most important fishing communities of the Midriff Islands region, Gulf of California, Mexico, which is an area of exceptional value for fisheries and conservation. In both cases, insufficient support from the government in provision of secure rights, enforcement and sanctioning, and recognition and incorporation of local arrangements and capacities for management arose as important needs to address.

In order to achieve long-term sustainability of fishery resources in the region, it is critical to consider formal and informal rulesin-use, as well as mechanisms for management and enforcement and their interactions at multiple levels (for example, land vs. sea institutions, higher level vs. local level governance). Understanding these intricate interactions, including how fishers perceive and defend their territory, may help managers devise strategies for management and enforcement that make sense to resource users, thus leading to improved opportunities for the long-term conservation of fishery resources.

Responses to this article can be read online at: http://www.ecologyandsociety.org/issues/responses. $\mathrm{php} / 5570$

\section{Acknowledgments:}

This study was made possible by contributions from the Wallace Research Foundation and the David and Lucile Packard Foundation through a grant to the PANGAS Project at The University of Arizona. We would like to express our gratitude to the fishers, license holders, and other community members who kindly participated in this research; to the personnel of CONAPESCA in Bahia de Kino (Sonora), the personnel of CONAPESCA and SEMARNAT in Ensenada (Baja California), and the personnel of CONANP in Bahía de los Ángeles (Baja California) for collaborating and providing information; to César Moreno, Mario Rojo, and Jorge Torre from COBI, and Amy Hudson Weaver from Niparajá, for their support and guidance during fieldwork in Bahía de Kino; and to Gustavo Danemann from Pronatura Noroeste for his support during fieldwork in Bahía de los Ángeles; to William Shaw, Edella Schlager, Richard Cudney-Bueno, Thomas Sheridan, and Tad Pfister for their invaluable guidance during this research. We are thankful to two anonymous reviewers for their time and valuable insights and observations. Special thanks to José (Lobo) Orensanz for reviewing the manuscript. Informed consent was obtained for experimentation with human subjects. This paper represents the views of the authors and not necessarily those of their institutions and funders. This is a scientific contribution of the PANGAS Project, www.pangas.arizona.edu.

\section{LITERATURE CITED}

Agrawal, A. 2001. Common property institutions and sustainable governance of resources. World Development 29(10):1649-1672. http://dx.doi.org/10.1016/S0305-750X(01)00063-8

Alcalá, G. 2003. Políticas Pesqueras en México, 1946-2000. Contradicciones y Aciertos en la Planificación de la Pesca Nacional. El Colegio de México, Centro de Investigación Científica y de Educación Superior de Ensenada, El Colegio de Michoacán, México.

Álvarez-Borrego, S. 2007. Oceanografía. Pages 45-65 in G. D. Danemann, and E. Ezcurra, editors. Bahía de los Ángeles: Recursos Naturales y Comunidad, Linea Base 2007. Pronatura Noroeste A.C., Secretaría de Medio Ambiente y Recursos Naturales, Instituto Nacional de Ecología, San Diego Natural History Museum.

Arce-Ibarra, A. M., and A. Charles. 2008. Non-management of natural resources: the case of Inland Fisheries in the Mayan Zone, Quintana Roo, Mexico. Human Ecology 36:853-860. http://dx. doi.org/10.1007/s10745-008-9201-6 
Avendaño-Ceceña, L. 2007. Bases para el Manejo de la Pesquería del Pepino de Mar (Isostichopus fuscus) en Bahía de los Ángeles, Baja California, México. MSc thesis. Universidad Autónoma de Baja California, Ensenada, Baja California, México.

Avendaño-Ceceña, L., E. Torreblanca, C. D. Morales, and R. Vale. 2009. Censo de pescadores, embarcaciones y artes de pesca de la comunidad de Bahía de los Ángeles. Documento técnico. Pronatura Noroeste, A.C. Calle décima \#60 esq. con Ryerson zona centro, Ensenada, Baja California, México.

Basurto, X. 2005. How locally designed access and use controls can prevent the tragedy of the commons in a Mexican small-scale fishing community. Society and Natural Resources 18:643-659. http://dx.doi.org/10.1080/08941920590959631

Basurto, X. 2006. Commercial diving and the Callo de Hacha fishery in Seri Territory. Journal of the Southwest 48:189-209.

Beebe, J. 1995. Basic concepts and techniques of rapid appraisal. Human Organization 54:42-51.

Berkes, F., J. Colding, and C. Folke. 2003. Navigating socialecological systems: building resilience for complexity and change. Cambridge University Press, Cambridge, U.K.

Berkes, F., R. Mahon, P. McConney, R. Pollnac, and R. S. Pomeroy. 2001. Managing small-scale fisheries. alternative directions and methods. International Development Research Centre (IDRC), Ottawa, Ontario, Canada.

Berkes, F. 2006. From community-based resource management to complex systems. Ecology and Society 11(1):45. [online] URL: http://www.ecologyandsociety.org/vol11/iss1/art45/

Bernard, H. R. 2006. Research methods in anthropology: qualitative and quantitative approaches. Altamira Press, Oxford, UK.

Bourillón, L. 2002. Exclusive fishing zone as a strategy for managing fishery resources by the Seri indians, Gulf of California, Mexico. Dissertation. The University of Arizona, Tucson, Arizona, USA.

Calderón-Aguilera, L. E., and M. D. Herrero-Pérezrul. 2011. La pesquería de pepino de mar Isostichopus fuscus en Baja California: un colapso inminente. Congreso Latinoamericano de Equinodermos (CLE), 13-18 noviembre de 2011, Puerto Madryn, Chubut, Argentina.

Carvajal, M. A., E. Ezcurra, and A. Robles. 2004. The Gulf of California: natural resource concerns and the pursuit of a vision. Pages 105-123 in L. K. Glover, and S. A. Earl, editors. Defying ocean's end: an agenda for action. Island Press, Washington, D. C., USA.

Charles, A. 2002. Use rights and responsible fisheries: limiting access and harvesting through rights-based management. Pages 127-155 in K. Cochrane, editor. A fishery manager's guidebook: management measures and their application. FAO Fisheries Technical paper No. 424. FAO, Rome, Italy.

Christy, F. T. 2000. Common property rights: an alternative to ITQs. Pages 118-135 in R. Shotton, editor. Proceedings of the Fish Rights 99 Conference, 11-19 November 1999, Freemantle,
Western Australia. FAO Fisheries Technical Paper 404/1. Fisheries Western Australia, Perth, Western Australia, Australia; and FAO, Rome, Italy.

Cinner, J. E., X. Basurto, P. Fidelman, J. Kuange, R. Lahari, and A. Mukminin. 2012. Institutional designs of customary fisheries management arrangements in Indonesia, Papua New Guinea, and Mexico. Marine Policy 36(1):278-285. http://dx.doi. org/10.1016/j.marpol.2011.06.005

Cinti, A., W. Shaw, R. Cudney-Bueno, and M. Rojo. 2010a. The unintended consequences of formal fisheries policies: social disparities and resource overuse in a major fishing community in the Gulf of California, Mexico. Marine Policy 34:328-339. http:// dx.doi.org/10.1016/j.marpol.2009.08.002

Cinti, A., W. Shaw, and J. Torre, 2010b. Insights from the users to improve fisheries performance: fishers' knowledge and attitudes on fisheries Policies in Bahía de Kino, Gulf of California, Mexico. Marine Policy 34:1322-1334. http://dx.doi.org/10.1016/j. marpol.2010.06.005

Cisneros-Mata, M. A. 2010. The importance of fisheries in the Gulf of California and ecosystem-based sustainable comanagement for conservation. Pages 119-134 in R. C. Brusca, editor. The Gulf of California: biodiversity and conservation. Arizona-Sonora Desert Museum Studies in Natural History. The University of Arizona Press, Tucson, Arizona, USA.

Cudney-Bueno, R., and X. Basurto. 2009. Lack of cross-scale linkages reduces robustness of community-based fisheries management. PLoS ONE 4:e6253. http://dx.doi.org/10.1201/ $\underline{\text { b14535-9 }}$

Danemann, G. D., and E. Ezcurra, editors. 2007. Bahía de los Ángeles: Recursos Naturales y Comunidad, Linea Base 2007. Pronatura Noroeste A.C., Secretaría de Medio Ambiente y Recursos Naturales, Instituto Nacional de Ecología, San Diego Natural History Museum.

Diario Oficial de la Federación. 1994. Norma Oficial Mexicana NOM-059-ECOL-1994 que determina las especies y subespecies de flora y fauna silvestres terrestres y acuáticas en peligro de extinción, amenazadas, raras y las sujetas a protección especial, y que establece especificaciones para su protección. DOF, México, D.F.

Diario Oficial de la Federación. 2000. Ley General de Vida Silvestre. 3 de Julio de 2000. DOF, México, D.F.

Diario Oficial de la Federación. 2007a. Ley General de Pesca y Acuacultura Sustentables. 24 de Julio de 2007. DOF, México, D.F.

Diario Oficial de la Federación. 2007b. Decreto de creación del área natural protegida Bahía de los Ángeles, Canales de Ballenas $y$ de Salsipuedes. 5 de junio de 2007. DOF, México, D.F.

Doode, S. 2001. La nueva Ley de Pesca y sus efectos en Sonora. Pages 9-19 in Lo que el 27 se llevó. Cambios urbanos, mineros, pesqueros, agrícolas, ganaderos y ecológicos en los ejidos Sonorenses. Cuaderno de Trabajo $N^{\circ} 1$. Red Fronteriza de Salud y Ambiente, The Sonoran Institute, and El Colegio de Sonora. Hermosillo, Sonora, México. 
Duberstein, J. N. 2009. The shape of the commons: social networks and the conservation of small-scale fisheries in the Northern Gulf of California, Mexico. Dissertation. The University of Arizona, Tucson, Arizona, USA.

Ensminger, J. 1996. Culture and property rights. In C. F. Hanna, and K. G. Maler, editors. Rights to nature: ecological, economic, cultural, and political principles of institutions for the environment. Island Press., Washington, D.C., USA.

FAO. 2002. Report and documentation of the International Workshop on Factors of Unsustainability and Overexploitation in Fisheries. Food and Agriculture Organization of the United Nations (FAO). Bangkok, Thailand.

Fernández, E. 2003. Bends in the bay: the nature of risk among commercial diving fishermen in Bahía de Kino, Sonora, Mexico. MSc thesis. The University of Arizona, Tucson, Arizona, USA.

Greenberg, J. B. 2006. The political ecology of fisheries in the Upper Gulf of California. In A. Biersack, and J. B. Greenberg, editors. Reimagining political ecology. Duke University Press, Durham, North Carolina, and London.

Hay, L. 2005. Qualitative research methods in human geography. Oxford University Press, Oxford, U.K., and New York, New York, USA.

Hilborn, R. 2005. Fishing rights or fishing wrongs? Reviews in Fish Biology and Fisheries 15:191-9. http://dx.doi.org/10.1007/ s11160-005-5138-7

Hilborn, R., J. M. Orensanz, and A. M. Parma. 2005. Institutions, incentives and the future of fisheries. Philosophical Transactions of The Royal Society B:47-57. http://dx.doi.org/10.1098/ rstb.2004.1569

Johannes, R. E. 1978. Traditional conservation methods in Oceania and their demise. Annual Review of Ecology and Systematics 9:349-64. http://dx.doi.org/10.1146/annurev. es.09.110178.002025

Mahon, R. 1997. Does fisheries science serve the needs of managers of small stocks in developing countries? Canadian Journal of Fisheries and Aquatic Sciences 54:2207-2213.

Moreno, C., A. Weaver, L. Bourillón, J. Torre, J. Égido, and M. Rojo. 2005a. Diagnóstico Ambiental y Socioeconómico de la Región Marina-Costera de Bahía de Kino, Isla Tiburón, Sonora México: Documento de trabajo y discusión para promover un desarrollo sustentable. Comunidad y Biodiversidad, Asociación Civil, Guaymas, Sonora, México.

Moreno, C., J. Torre, L. Bourillón, M. Durazo, A. Weaver, R. Barraza, and R. Castro. 2005b. Estudio y Evaluación de la Pesquería de Callo de Hacha (Atrina tuberculosa) en la Región de Bahía de Kino, Sonora y Recomendaciones para su Manejo. Reporte interno. Comunidad y Biodiversidad, Asociación Civil, Guaymas, Sonora, México.

Moreno-Báez, M. 2010. Mapping the human dimensions of smallscale fisheries in the Northern Gulf of California, México. Dissertation. The University of Arizona, Tucson, Arizona, USA.

Moreno-Báez, M., B. J. Orr, R. Cudney-Bueno, and W. W. Shaw. 2010. Using fishers' local Knowledge to aid management at regional scales: spatial distribution of small-scale fisheries in the Northern Gulf of California, Mexico. Bulletin of Marine Science 86(2):339-353.

Orensanz, J. M., A. Cinti, A. M. Parma, L. Burotto, S. EspinosaGuerrero, E. Sosa-Cordero, C. Sepúlveda, and V. Toral-Granda. 2013, in press. Latin-American rights-based fisheries targeting sedentary resources. In J. M. Orensanz, and J. C. Seijo, editors. Rights-based management in Latin American fisheries. FAO Fisheries and Aquaculture Technical Paper 582, Rome, Italy.

Orensanz, J. M., A. M. Parma, G. Jerez, N. Barahona, M. Montecinos, and I. Elías. 2005. What are the key elements for the sustainability of "S-fisheries"? Insights from South America. In N. Erhardt, editor. Bulletin of Marine Science 76:527-556.

Ostrom, E. 1990. Governing the commons: the evolution of institutions for collective actions. Cambridge University Press, Cambridge, UK. http://dx.doi.org/10.1017/CBO9780511807763

Ostrom, E. 1992. Diseño de Instituciones para Sistemas de Riego Auto-Gestionarios. Institute for Contemporary Studies, San Francisco, California, USA.

Ostrom, E. 1999. Coping with tragedies of the commons. Annual Review of Political Science 2:493-535. http://dx.doi.org/10.1146/ annurev.polisci.2.1.493

Ostrom, E., T. Dietz, N. Dolsak, P. C. Stern, S. Stonich, E. U. Weber, editors. 2002. The drama of the commons. Committee on the Human Dimensions of Global Change, Division of Behavioral and Social Sciences and Education, National Research Council. National Academy Press, Washington, D.C., USA.

Ostrom, E. 2007. A diagnostic approach for going beyond panaceas. Proceedings of the National Academy of Science 104 (39):15181-15187. http://dx.doi.org/10.1073/pnas.0702288104

Sánchez-Luna, G. 1995. Algunas notas en relación con la tenencia de la tierra en México. Boletín Mexicano de Derecho Comparado, $\mathrm{N}^{\circ} 84$.

Valdez, V. M., and E. Torreblanca. 2008. Diagnóstico pesquero de la Reserva de la Biosfera "Bahía de los Ángeles, Canales de Ballenas $y$ de Salsipuedes”. Pronatura Noroeste, A.C. Calle décima \#60 esq. con Ryerson zona centro, Ensenada, B.C., México.

Vargas, M. A., F. Ochoa, and G. D. Danemann. 2007. Tenencia de la tierra y conservación de tierras privadas. Pages 679-693 in G. D. Danemann and E. Ezcurra, editors. Bahía de los Ángeles: Recursos Naturales y Comunidad, Línea Base 2007. Pronatura Noroeste A.C., Secretaría de Medio Ambiente y Recursos Naturales, Instituto Nacional de Ecología, San Diego Natural History Museum.

${ }^{[1]}$ Common pool resources are ones for which exclusion from the resource is costly and one person's use subtracts from what is available to others (Ostrom et al. 2002).

${ }^{[2]}$ Sociedades de Producción Rural are a special type of formal organization commonly found in rural industry, service, and production activities, including fisheries.

${ }^{[3]}$ Ejidos, agrarian communities, and indigenous communities are different juridical forms of communal land tenure (see SánchezLuna 1995). 